\title{
ANALISIS PERUBAHAN GARIS PANTAI MENGGUNAKAN DIGITAL SHORELINE ANALYSIS SYSTEM DI KECAMATAN KUALA PESISIR, KABUPATEN NAGAN RAYA, ACEH
}

\author{
Fahreza Okta Setyawan $^{\text {a,*, Wahida Kartika Sari, }}{ }^{\text {, }}$, Dian Aliviyantia

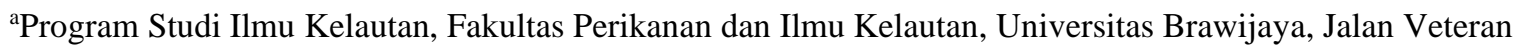 \\ Malang, Indonesia

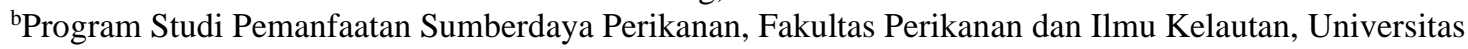 \\ Brawijaya, Jalan Veteran Malang, Indonesia \\ *Koresponden penulis : setyawan.fos@ub.ac.id
}

\begin{abstract}
Abstrak
Perubahan garis pantai merupakan salah satu bentuk dinamisasi pada kawasan pantai yang dapat terjadi secara terus menerus. Faktor penyebab terjadinya perubahan garis pantai dapat diakibatkan oleh adanya abrasi dan akresi. Faktor hidro - oseanografi yang juga mempengaruhi perubahan garis pantai yaitu gelombang dan pasang surut air laut. Secara umum, penyebab terjadinya gelombang laut yang dominan yaitu diakibatkan oleh faktor aingin. Tujuan dari penelitian ini adalah untuk mengetahui perubahan garis pantai serta hubungan antara perubahan garis pantai dengan pasang surut dan gelombang laut yang terjadi di Pantai Gampong Lhok, Aceh. Metode yang digunakan dalam penelitian ini yaitu metode thresholding untuk memisahkan antara daratan dengan lautan dan pengaplikasian Digital Shoreline Analysis System (DSAS). Hasil penelitian yang didapatkan yaitu selama rentang waktu tahun 2016 - 2020 kawasan pesisir Pantai Gampong Lhok mengalami akresi maksimum sebesar 30,16 m/tahun, sedangkan abrasi maksimum terjadi sebesar $-34,49 \mathrm{~m} /$ tahun. Hasil penelitian ini dapat digunakan sebagai penelitian awal dalam pembuatan kebijakan oleh pemerintah untuk kawasan pesisir Pantai Gampong Lhok.
\end{abstract}

Kata kunci: Aceh, DSAS, Gelombang, Pasang Surut

\begin{abstract}
The change of coastline is one form of dynamism in coastal areas that can occur continuously. The causative factors of changes in the coastline can be caused by abrasion and accretion. Hydro factor - oceanography that also affects the changes in the coastline, namely waves and tides. In general, the dominant cause of ocean waves is caused by wind factor. The purpose of this study is to find out the changes in the coastline also the connection between changes in the coastline with the tides and ocean waves that occur in Gampong Lhok Beach, Aceh.The method used in this study is thresholding method to separate between land and ocean and application of Digital Shoreline Analysis System (DSAS). The results of the study obtained in 2016 -2020 coastal areas of Gampong Lhok Beach experienced a maximum accretion of $30,16 \mathrm{~m} /$ year, while the maximum abrasion occurred at $-34,49 \mathrm{~m} /$ year. Ther results of this study can be used as preliminary research in policy making by the government for the coastal area of Gampong Lhok Beach.
\end{abstract}

Keywords: Aceh, DSAS, Waves, Tides

\section{PENDAHULUAN}

Indonesia merupakan negara maritim dengan luas perairan yang lebih besar dibandingkan dengan luas daratannya. Lebih dari 3.700 pulau dan wilayah pantai dengan panjang $80.000 \mathrm{~km}$ dimikili oleh negara Indonesia [1]. Wilayah pantai dapat didefinisikan sebagai suatu daerah yang berada ditepi perairan dan dipengaruhi oleh air pasang tertinggi serta air surut terendah, sedangkan garis pantai merupakan garis batas pertemuan antara daratan dengan air laut yang memiliki posisi dinamis. Garis pantai memiliki posisi yang tidak tetap dan dapat berpindah sesuai dengan pengaruh pasang surut air laut, dan erosi pantai yang terjadi [10]. Faktor lain yang dapat mempengaruhi perubahan garis pantai adalah angin, gelombang, arus, jenis serta material pantai yang berpengaruh terhadap 
proses sedimentasi, gerakan air, morfologi pantai, dan juga adanya perbedaan nilai laju penurunan muka tanah antara satu tempat dengan tempat lainnya. Umumnya nilai laju penurunan muka tanah akan semakin besar apabila mendekati pantai. Penurunan muka tanah yang terjadi pada kawasan pantai dapat memicu terjadinya abrasi dan akresi. Abrasi pantai merupakan proses mundurnya garis pantai dari posisi asalnya, abrasi dapat dikategorikan sebagai salah satu faktor permasalahan yang mengancam kemunduran garis pantai. Abrasi juga dapat merusak penggunaan lahan serta bangunan - bangunan yang terdapat pada pinggir pantai. Akresi merupakan proses majunya garis pantai, penyebab terjadinya akresi yaitu adanya proses sedimentasi yang berasal dari daratan ke lautan. Faktor - faktor penyebab terjadinya proses sedimentasi yaitu adanya pembukaan lahan, besarnya volume limpasan air, dan juga adanya transport sedimen dari badan sungai menuju lautan [1].

Gelombang laut didefinisikan sebagai pergerakan naik turunnya air dengan arah tegak lurus permukaan air laut yang selanjutnya membentuk kurva sinusoidal. Pembentukan gelombang umumnya dapat terjadi di daerah perairan lepas. Pada saat gelomang terbentuk maka gelombang tersebut akan bergerak dalam jarak yang panjang dalam melintasi laut, dengan hanya kehilangan sedikit dari energinya. Gelombang laut tersebut merupakan salah satu parameter laut yang domain terhadap laju mundurnya garis pantai [10]. Gelombang merupakan salah satu faktor hidro - oseanografi yang berpengaruh terhadap dinamika di lautan. Gelombang yang terjadi di lautan dapat diklasifikasikan berdasarkan pada pembangkitnya. Pembangkit gelombang laut dapat diakibatkan oleh angin (gelombang angin), gelombang akibat gaya Tarik menarik bumi dengan bulan dan matahari (gelombang pasang surut), gempa (vulkanik ataupun tektonik) di laut (gelombang tsunami), dan gelombang yang disebabkan oleh gerakan kapal. Gelombang laut dan arah pergerakan arus permukaan laut dapat dipengaruhi oleh angin musim, pergerakan musiman air permukaan laut sangat erat kaitannya dengan pola musim [4].
Pasang surut merupakan suatu fluktuasi muka air laut yang disebabkan oleh gaya tarik menarik benda - benda di langit, terutama matahari dan bulan terhadap massa air laut bumi. Meskipun massa bulan jauh lebih kecil dibandingkan dengan massa matahari, namun jarak bulan terhadap bumi jauh lebih dekat, oleh karena itu pengaruh gaya tarik bulan terhadap bumi jauh lebih besar dibandingkan pengaruh gaya tarik matahari. Gaya tarik bulan yang mempengaruhi pasang surut yaitu 2,2 kali lebih besar dibandingkan dengan gaya tarik matahari. Gaya tarik-menarik antara bumi dan bulan tersebut selanjutnya mengakibatkan sistem bumi-bulan menjadi satu sistem kesatuan yang beredar bersama - sama pada sekeliling sumbu perputaran bersama. Pembentukan pasang surut air laut sangat erat kaitannya dengan gerakan utama matahari dan bulan, diantaranya yaitu revolusi bulan terhadap bumi, revolusi bumi terhadap matahari, dan perputaran bumi terhadap sumbunya sendiri [3].

Wilayah pantai Aceh Barat yang merupakan pantai dengan kondisi yang landai, kawasan ini berbatasan langsung dengan Samudera Hindia yang memiliki karakteristik oseanografi dan dinamika perairan yaitu tingginya gelombang laut dan juga angin kencang. Aceh Barat memiliki panjang garis pantai $50,55 \mathrm{~km}$ dengan luas perairan lautnya yaitu $80,88 \mathrm{~km}^{2}$. Perubahan terhadap garis pantai merupakan salah satu bentuk dari dinamisasi kawasan pantai yang terjadi secara terus menerus. Pantai yang berada di Aceh Barat tersebut rentan akan pergerakan sedimen yang memberi dampak pada mundurnya garis pantai (abrasi) serta majunya garis pantai (akresi) [8]. Penelitian ini bertujuan untuk mengetahui nilai perubahan garis pantai di wilayah Pantai Gampong Lhok, Aceh pada tahun 2016 - 2020 dengan menggunakan Digital Shoreline Analysis System (DSAS) serta untuk mengetahui hubungan garis pantai dengan faktor hidro-oseanografi pasang surut dan gelombang laut. 


\section{METODE}

\section{Lokasi Penelitian}

Lokasi penelitian berada sepanjang pesisir Pantai Gampong Lhok, Kecamatan Kuala Pesisir (Gambar 1). Lokasi penelitian ini dibatasi oleh wilayah administrasi daerah, dimana sebelah utara berbatasan dengan Kecamatan Kuala, sebelah timur berbatasan dengan Kecamatan Tadu Raya dan sebelah selatan berbatasan dengan Kabupaten Aceh Barat. Observasi data garis pantai dilakukan pada tahun 2016 - 2020 dengan skala peta 1 : 40.000

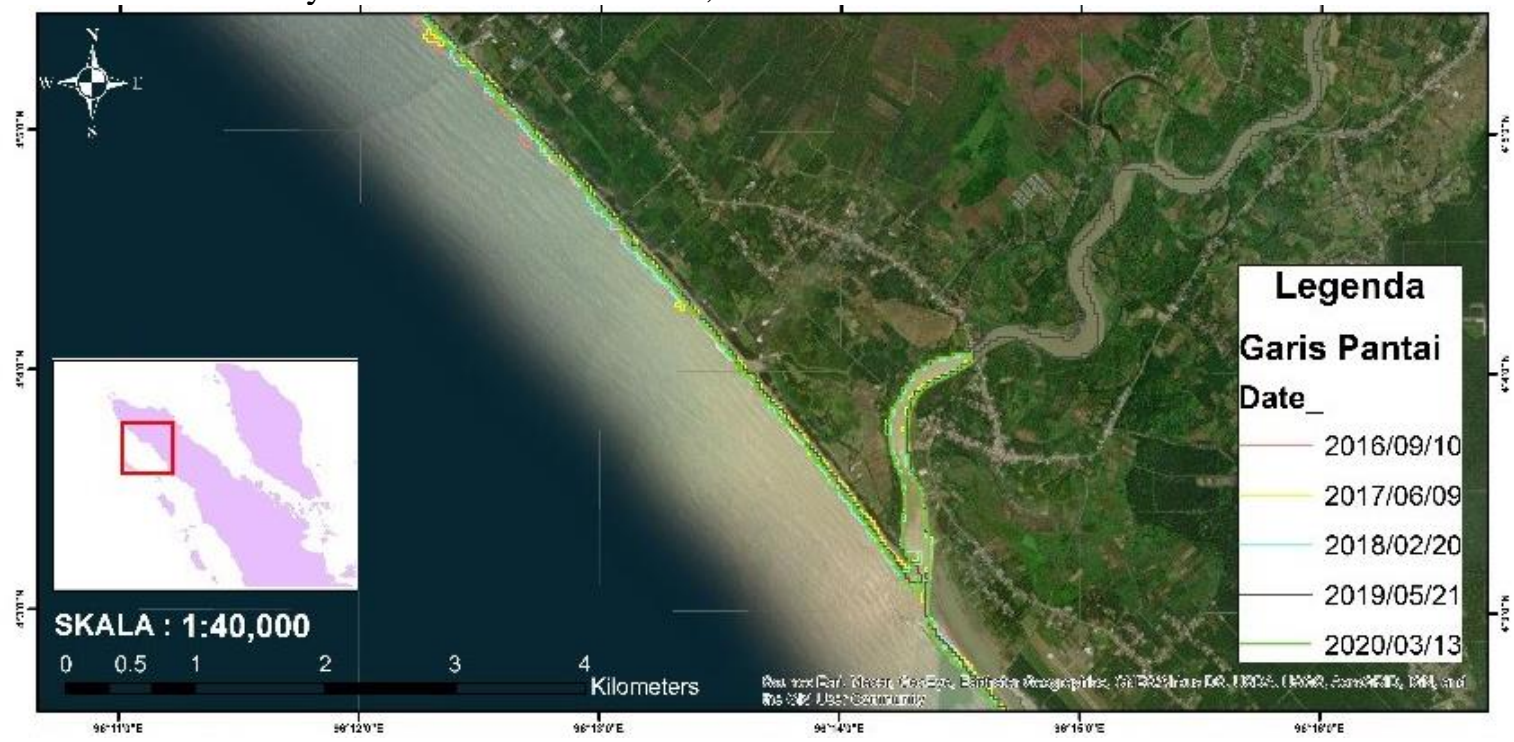

Gambar 1. Lokasi Penelitian Pantai Gampong Lhok, Aceh Barat

\section{Dataset}

Teknik pengambilan data dilakukan secara sekunder, yaitu diperoleh melalui proses pengunduhan pada beberapa laman penyedia data spasial dan hidro-oseanografi. Adapun berikut adalah data yang digunakan pada penelitian ini yaitu citra satelit, data angin, data gelombang, dan data pasang surut.

Citra merupakan gambaran yang terekam oleh kamera atau sensor lainnya dan dipasang pada wahana satelit ruang angkasa dengan ketinggian lebih dari $400 \mathrm{~km}$ dari permukaan bumi. Pada penelitian ini, data citra satelit yang digunakan diperoleh dari satelit Landsat 8 dengan sensor OLI/TIRS C1 Level-1 dan waktu perekaman (10/09/2016;09/06/2017; 20/02/2018;21/05/2019;13/03/2020) [6]. Data ini dapat diunduh secara gratis melalui laman https://earthexplorer.usgs.gov/.

Angin menjadi faktor pembentukan gelombang yang berpengaruh terhadap dinamika garis pantai. Data angin sangat penting kaitannya dalam penelitaian terkait perubahan garis pantai. Dari data angin, dapat diketahui arah dan kecepatan angin yang berhembus pada suatu perairan pada periode tertentu. Sehingga dapat dihubungkan dengan gelombang yang terbentuk pada sekitar pantai. Data angin diperoleh melalui laman https://cds.climate.copernicus.eu/.

Gelombang erat kaitannya dengan kondisi geomorfologi suati pantai. Data tinggi dan periode gelombang digunakan untuk mengetahui pengaruhnya terhadap perubahan garis pantai yang terjadi pada daerah penelitian. Data gelombang diperoleh melalui laman https://cds.climate.copernicus.eu/.

Data pasang surut digunakan untuk mengetahui kondisi pasang surut dan tinggi muka air laut yang terjadi pada saat dilakukan akuisisi data citra satelit. Tujuannya adalah untuk memastikan bahwa kondisi pasang surut yang terjadi pada saat akuisisi data citra satelit sama, serta tidak memiliki perbedaan ketinggian muka air laut yang terlalu jauh sehingga tidak memiliki pengaruh yang signifikan terhadap proses pemisahan darata 
dan laut. Data pasang surut diperoleh melalui laman https://tides.big.go.id/pasut/.

\section{Analisis Data}

Metode thresholding atau dapat disebut dengan thresholding citra merupakan suatu metode yang digunakan untuk membedakan gambar input ke dalam dua kelas piksel yang memilki nilai kurang dari threshold dan lebih dari threshold. Secara umum, citra yang akan dilakukan pengolahan dapat mengaplikasikan threshold pada citra gray level untuk dapat menghasilkan citra biner yang merupakan citra dengan nilai lebel keabuan 0 atau 255 [1]. Digital Shoreline Analysis System (DSAS) adalah suatu perangkat lunak tambahan yang bekerja pada perangkat lunak ArcGIS yang dikembangkan oleh ESRI dan USGS yang dapat diperoleh secara gratis.

Digital Shoreline Analysis System (DSAS) merupakan perangkat lunak yang dapat digunakan untuk menghitung laju perubahan garis pantai dari waktu ke waktu secara otomatis menggunakan titik sebagai acuan pengukurannya. Beberapa perhitungan yang dapat dilakukan dengan DSAS diantaranya Shoreline Change Envelope (SCE), Net Shoreline Movement (NSM), End Point Rate (EPR) dan Linear Regression Rate (LRR). Dengan menggunakan metode ini kita akan dapat mengamati perubahan apa saja yang terjadi, apakah terjadi abrasi atau terjadi akresi di wilayah tersebut [7]

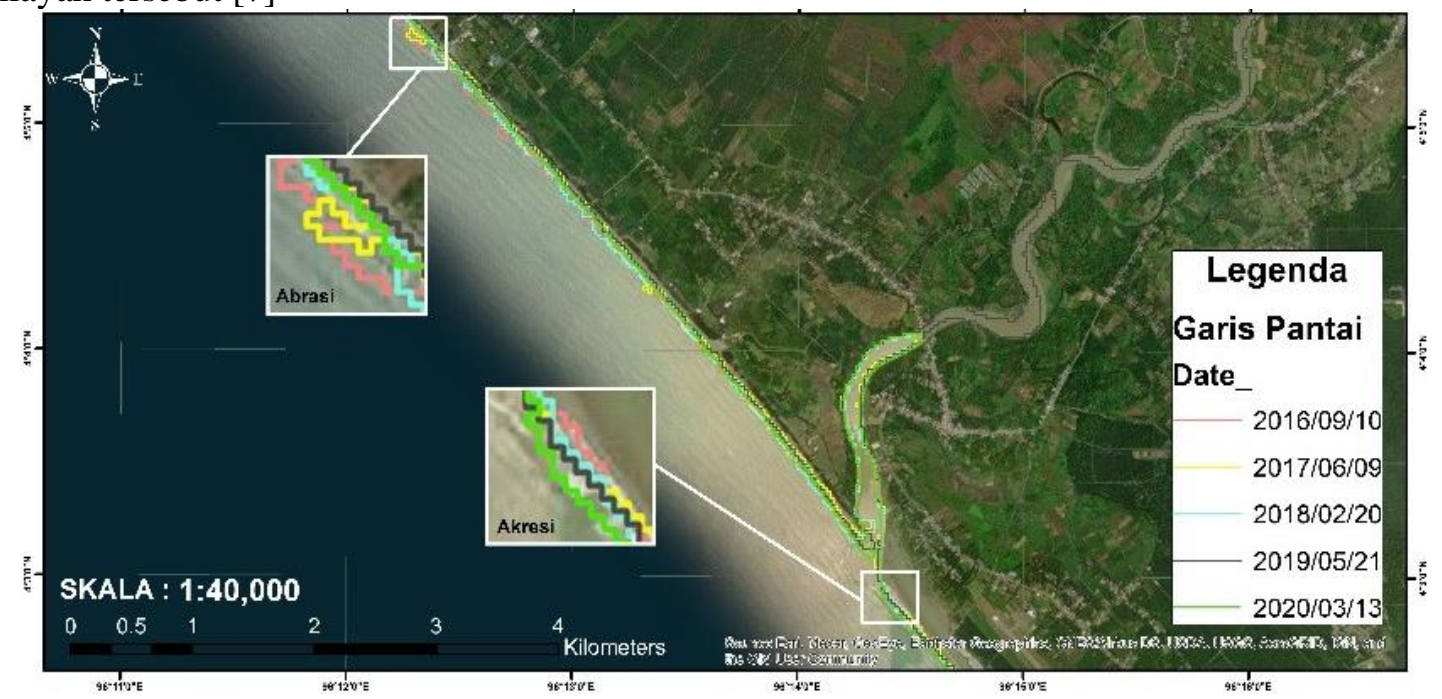

Gambar 2. Peta Perubahan Garis Pantai disertai Daerah Perbesaran

\section{HASIL DAN PEMBAHASAN}

\section{Perubahan Garis Pantai}

Berdasarkan peta perubahan garis pantai (Gambar 2), diketahui terdapat dua segmen/transek yang mengalami perubahan garis pantai yang paling signifikan selama kurun waktu 5 tahun. Apabila dijabarkan, dua segmen/transek tersebut yaitu segmen/transek 286 dimana terjadi akresi sedangkan segmen/transek 1259 terjadi abrasi (Gambar 3). Faktor yang dapat mempengaruhi terjadinya abrasi dan akresi yaitu gelombang dan pasang surut. Gelombang terjadi melalui proses pergerakan massa air, secara umum dibangkitkan oleh hembusan angin secara tegak lurus terhadap pantai. Gelombang merambat ke segala arah dengan membawa energi ketika sampai di pantai kemudian dilepaskan dalam bentuk hempasan ombak. Gelombang yang terjadi di daerah gelombang pecah mengandung energi begitu kuat dan sangat berperan untuk pembentukan morfologi pantai. Gelombang pecah mampu menggerakan atau mengangkut material dari lepas ke pantai sehingga terjadi proses akresi terhadap material di garis pantai [9] 


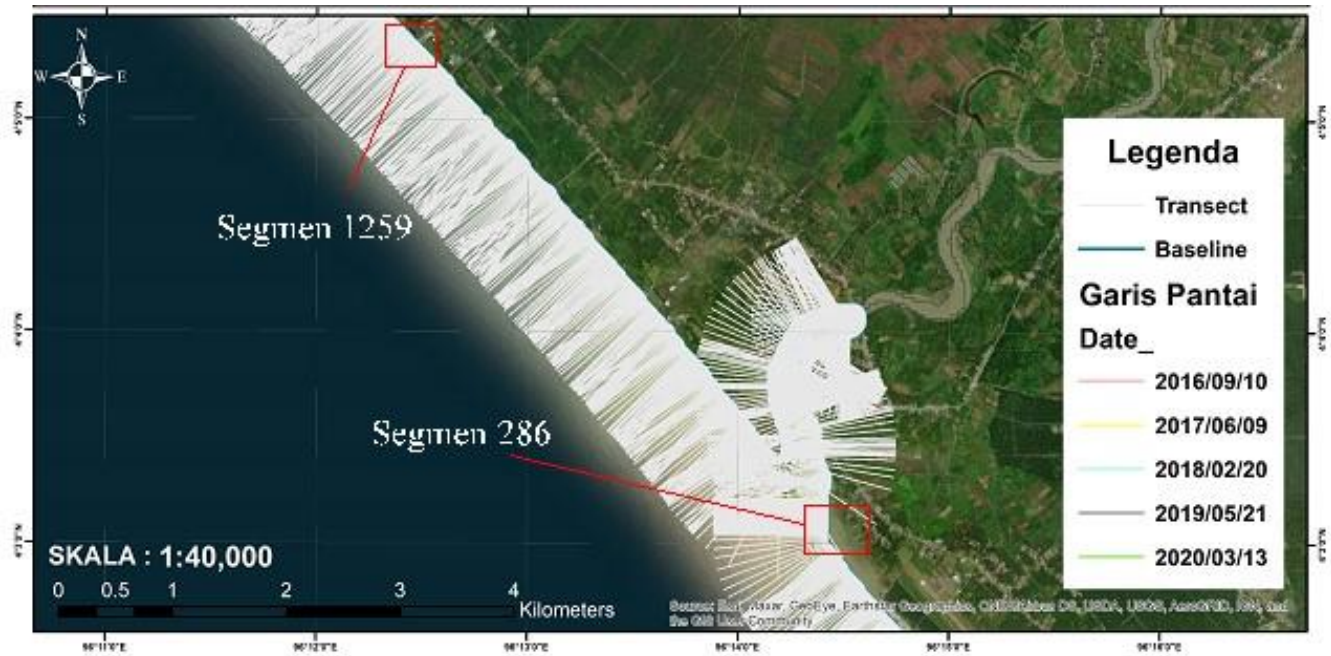

Gambar 3. Peta Segmen/transek Pantai Gampong Lhok, Aceh Barat

Hal yang sama juga diperoleh dari hasil perhitungan komponen DSAS yaitu berupa grafik NSM (Net Shoreline Movement), grafik SCE (Shoreline Change Envelope), dan grafik EPR (End Point Rate). Guna mengukur jarak perubahan posisi garis pantai antara garis yang terlama dan garis pantai terbaru maka dilakukan analisis NSM. Berdasarkan grafik tersebut (Gambar 4) disimpulkan bahwa perubahan garis pantai yang terjadi di kawasan pesisir Pantai Gampong Lhok bervariasi. Daerah yang mengalami akresi atau abrasi dapat dilihat dari nilainya (positif atau negatif). Pada wilayah kajian ini, nilai akresi tertinggi terletak pada segmen 286 sebesar 105,69 m, yang ditunjukkan dengan garis biru kearah atas (nilai positif) pada grafik Gambar 4. Sedangkan abrasi tertinggi terjadi pada segmen 1259 sebesar $-120,88 \mathrm{~m}$ yang ditunjukkan dengan garis biru kearah bawah (nilai negatif) pada grafik Gambar 4. Berdasarkan grafik itu juga, dapat diketahui rata - rata akresi yang terjadi yaitu sebesar $22,11 \mathrm{~m}$ sedangkan rata rata abrasi sebesar $-20,28 \mathrm{~m}$.

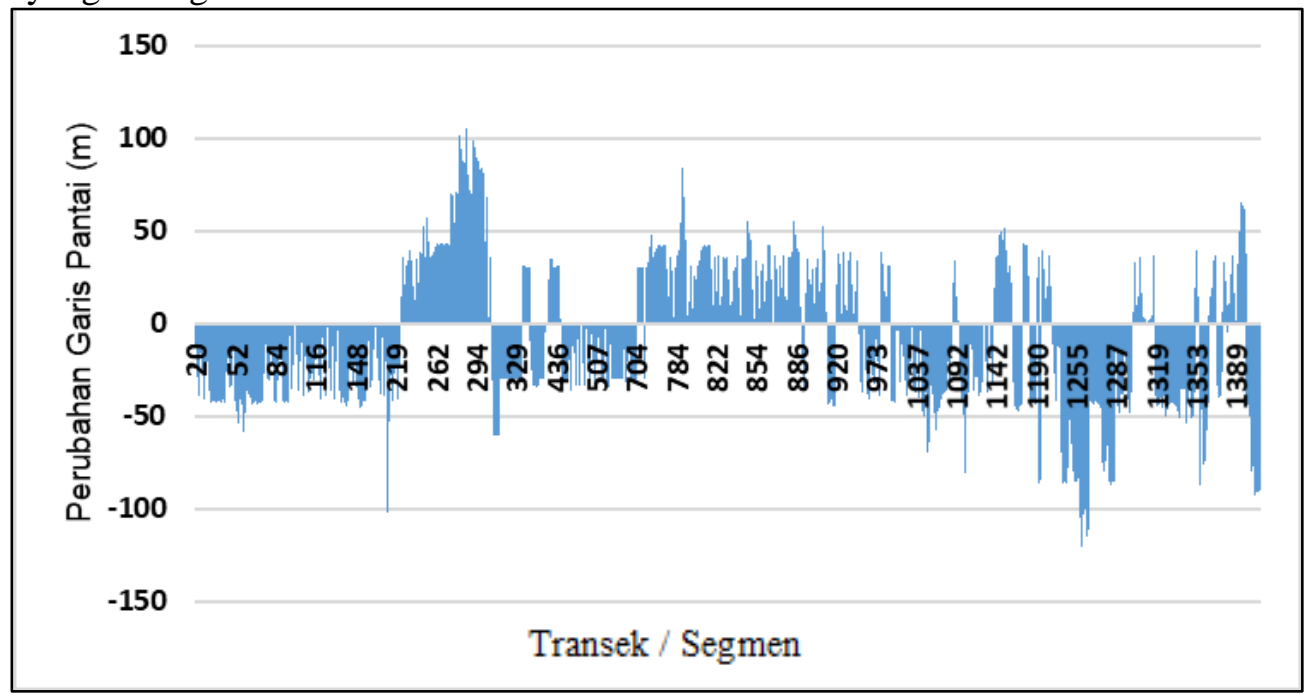

Gambar 4. Grafik NSM (Net Shoreline Movement) 
Selanjutnya guna menghitung jarak antara garis pantai dari baseline maka dilakukan analisis SCE (Shoreline Change Envelope). Berdasarkan grafik SCE (Gambar 5), dapat disimpulkan bahwa jarak terjauh garis pantai dengan baseline terdapat pada segmen 545 yaitu sebesar 201,2 m, yang ditunjukkan garis oranye yang paling menjulang ke atas. Dari grafik tersebut didapatkan nilai rata - rata 48,38 m. Hal ini menunjukkan bahwa pada segemen 545, telah terjadi perubahan garis pantai yang paling jauh dari baseline selama 5 tahun terakhir.

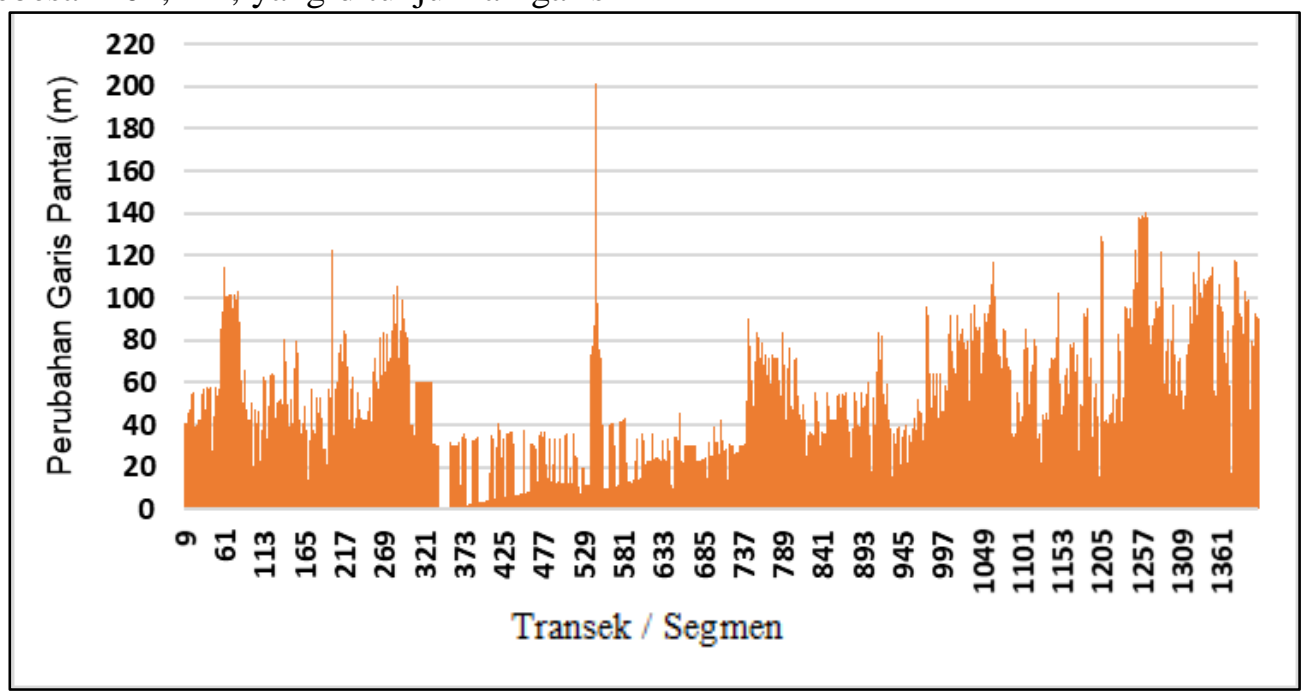

Gambar 5. Grafik SCE (Shoreline Change Envelope)

EPR (End Point Rate) digunakan untuk menghitung laju perubahan garis pantai dengan membagi jarak antara garis pantai terlama dan garis pantai terkini dengan waktunya. Berdasarkan grafi EPR (Gambar 6) dapat disimpulkan bahwa dari tahun 2016 - 2020, kawasan pesisir Pantai Gampong Lhok mengalami akresi maksimum sebesar 30,16 $\mathrm{m} /$ tahun yaitu pada segmen 286. Sedangkan abrasi maksimum sebesar -34,49 m/tahun terjadi pada segmen 1259. Berdasarkan grafik tersebut diketahui rata - rata laju akresi yang terjadi di kawasan pesisir Pantai Gampong Lhok sebesar $6,38 \mathrm{~m} /$ tahun. Sedangkan rata rata laju abrasi yang terjadi sebesar $-5,85$ $\mathrm{m} /$ tahun.

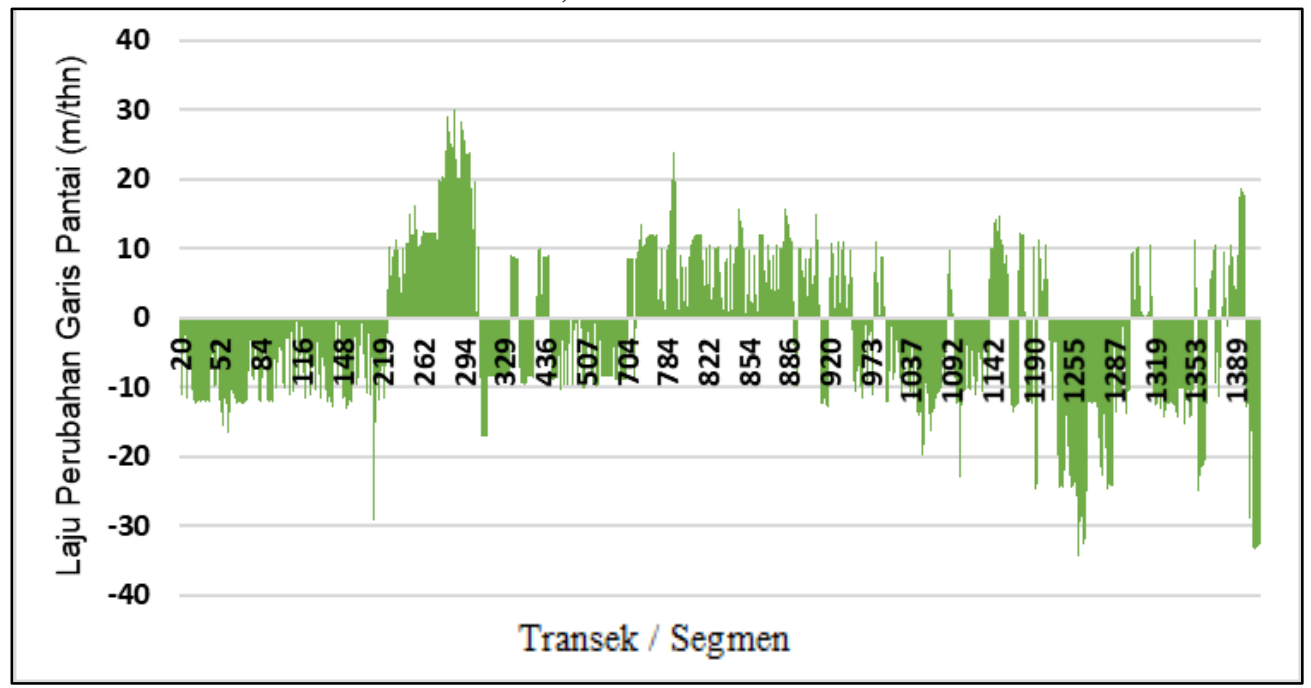

Gambar 6. Grafik EPR (End Point Rate) 
Kondisi pantai pada wilayah Aceh Barat merupakan pantai yang landau, saat ini mengalami pergeseran garis pantai yang menyebabkan kehilangan wilayah daratan dan mengancam lingkungan sekitarnya. Perubahan garis pantai merupakan salah satu bentuk dinamisasi kawasan pantai yang terjadi secara terus menerus. Pantai di Aceh Barat rentan terhadap pergerakan sedimen yang memberi dampak pada mundurnya garis pantai (abrasi) dan majunya garis pantai (akresi). Fenomena pergeseran garis pantai ini disebut dengan proses abrasi atau terjadinya kelongsoran pada bagian tepi pantai oleh karena pengikisan air laut. Salah satu kawasan yang memiliki tingkat abrasi yang cukup parah adalah di pesisir Kecamatan Meureubo. Penyebab abrasi pantai di wilayah ini diasumsikan dari proses alami (gelombang laut, pasang surut, angin, dan arus sepanjang pantai). Proses - proses alami dapat berupa proses hidro-oseanografi, dari laut misalnya akibat hempasan gelombang, perubahan pola arus, angin dan fenomena pasang surut yang semuanya dapat menyebabkan abrasi pantai. Pergerakan sedimen memberikan dampak terhadap perubahan geomorfologi, ketidakstabilan ekologi, dan kerusakan bangunan di sekitar pantai. Abrasi merupakan salah satu masalah yang mengancam kondisi pesisir, yang dapat merusak dan mengancam bangunan bangunan yang berbatasan langsung dengan air laut, baik bangunan yang difungsikan sebagai penunjang wisata maupun rumah - rumah penduduk [8]

\section{Angin dan Gelombang}

Angin menjadi salah satu faktor terjadinya perubahan garis pantai, meskipun pengaruhnya secara langsung masih kurang diperhitungkan. Apabila dijabarkan, angin menjadi faktor utama terhadap pembentukan gelombang. Gelombang yang menjalar dari laut ke darat akan mengalami gesekan dengan dasar laut pada kedalaman tertentu, sehingga turut serta membawa sedimen bersamanya. Hal ini berpengaruh terhadap pola sebaran sedimen di sekitar pantai. Semakin besar kecepatan angin yang berhembus, semakin besar juga gelombang yang dihasilkan. Gelombang membentuk sudut datang terhadap pantai, dapat menimbulkan arus sejajar pantai (littoral current). Arus inilah yang berperan besar terhadap pola persebaran sedimen di sepanjang kawasan pantai dan menghasilkan peristiwa abrasi dan akresi. Pada penelitian ini yang dibahas hanya sebatas pada arah dan kecepatan angin yang menyebabkan terbentuknya gelombang, sehingga masih diperlukan penelitian lebih lanjut terkait arus dan pola sebaran sedimen untuk menunjang kajian mengenai topik perubahan garis pantai secara terperinci.

Data angin dan gelombang yang digunakan dalam analisis kajian ini dikategorikan berdasarkan musim. Hal ini memudahkan dalam pengolahan data dan interpretasi. Berdasarkan windrose yang dihasilkan (Gambar 6), setiap musim memiliki arah angin yang bervairasi. Pada musim barat (Desember - Februari), angin cenderung bergerak dari arah Tenggara dengan nilai kecepatan dominan sebesar 2,1-3,60 m/s yang ditandai dengan warna kuning (Gambar 7 a.). Pada musim Peralihan I (Gambar 7 b.), dapat diketahui bahwa arah angin bergerak dari arah Barat Laut dengan nilai kecepatan dominan sebesar 2,1 - 3,60 m/s yang ditandai dengan warna kuning. Pada musim Timur (Gambar 7 c.), dapat diketahui bahwa arah angin bergerak dari arah Tenggara dengan nilai kecepatan dominan sebesar 2,1-3,60 m/s yang ditandai dengan warna kuning. Pada musim Peralihan II (Gambar 7 d.), dapat diketahui bahwa arah angin bergerak dari arah Barat Laut dengan nilai kecepatan dominan sebesar 3,6-5,7 m/s yang ditandai dengan warna merah. 

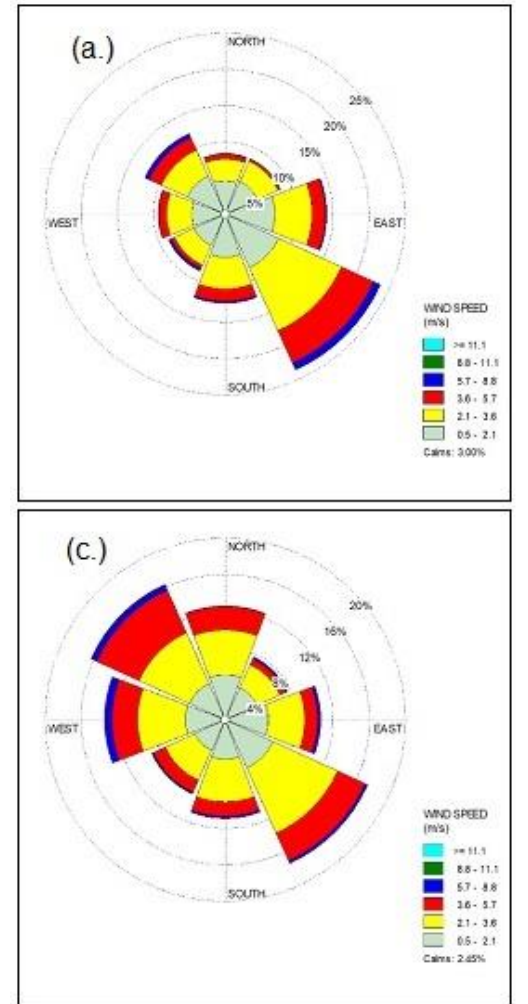
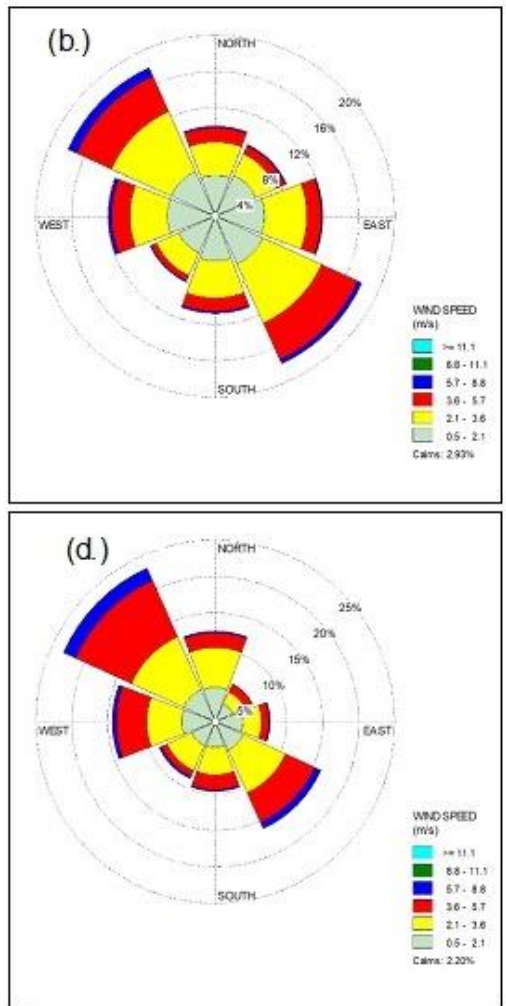

Gambar 7. Windrose 4 Musim, (a.) Musim Barat (Des-Feb), (b.) Musim Peralihan I (Mar-Mei), (c.) Musim Timur (Juni-Agus), (d.) Musim Peralihan II (Sept-Nov)

Berdasarkan hasil tersebut, maka dapat diketahui bahwa musim peralihan II memiliki kecepatan angin paling besar jika dibandingkan dengan musim lainnya. Hal ini menyebabkan tinggi dan periode gelombang di perairan Gampong Lhok pada musim peralihan II cenderung tinggi, hal ini ditandai dengan adanya angin berkekuatan sekitar 5,7-8,8 m/s. Kondisi wilayah perairan di lokasi penelitian, secara keseluruhan adalah laut terbuka menghadap ke Samudera Indonesia. Karakteristik pantai - pantai di Barat Sumatera adalah pengaruh angin musim yaitu angin dari arah Barat dan Selatan yang menyebabkan gelombang laut di daerah tersebut cenderung tinggi. Akibat perbedaan tinggi dan frekuensi kejadiannya menyebabkan adanya pergerakan sedimen yang dominan pada arah tertentu, dimana akibatnya sering terjadi akresi dan abrasi di beberapa pantai. Angin dari Selatan akan menyebabkan arah gelombang dominan menuju Utara, sedangkan angin Barat akan menyebabkan arah gelombang dominan menuju Timur [8].

Menurut [2], gelombang yang menjalar sebagian besar dibangkitkan oleh angin dan berpengaruh terhadap besarnya angkutan sedimen dari laut ke darat. Pergerakan angin di permukaan laut memiliki kecepatan yang beragam, kecepatan angin tersebut sangat berpengaruh untuk membangkitkan gelombang. Gelombang yang dating menuju pantai akan mengikis dan berpengaruh terhadap berubahnya garis pantai dan besarnya angkutan sedimen. Gelombang pecah dapat mengakibatkan terbentuknya arus sejajar pantai yang dapat memindahkan sedimen di sepanjang pantai. Besarnya sudut datang gelombang akan mempengaruhi pola arus sejajar pantai yang memungkinkan sedimen berpindah sepanjang pantai dan akan terendapkan pada daerah dimana kecepatan arusnya tidak memungkinkan lagi untuk memindahkan sedimen. Sehingga dapat dikatakan bahwa laju angkutan sedimen 
bergantung pada sudut datang gelombang, lama angin bertiup, dan energi gelombang.

\section{Pasang Surut}

Perpindahan massa air laut dari satu tempat ke tempat lain ketika pasang surut menyebabkan terjadinya arus pasang surut. Arus pasang surut berpengaruh terhadap proses pantai, seperti sebaran sedimen dan abrasi pantai. Pasang naik dapat menyebabkan sedimen ke dekat pantai. Sedangkan, ketika surut dapat menyebabkan majunya sedimen ke arah laut lepas [9]. Perbedaan nilai ketinggian pasang surut akan memiliki pengaruh terhadap perubahan garis pantai (akresi dan abrasi) di daerah penelitian. Namun tidak menutup kemungkinan faktor geomorfologi / kemiringan pantai juga turut berpengaruh terhadap besar kecilnya perbedaan rentang ketinggian muka air laut, sehingga pengaruh pasang surut pada setiap daerah memiliki perbedaan satu sama lain dan perlu dilakukan kajian lebih lanjut.

Tabel 1. Konstanta Harmonik Pasang Surut

\begin{tabular}{|rcccccccccc|}
\hline \multicolumn{10}{|c|}{ Prediksi Pasang Surut } \\
\hline & $\mathbf{S}_{\mathbf{0}}$ & $\mathbf{M}_{\mathbf{2}}$ & $\mathbf{S}_{\mathbf{2}}$ & $\mathbf{N}_{\mathbf{2}}$ & $\mathbf{K}_{\mathbf{1}}$ & $\mathbf{O}_{\mathbf{1}}$ & $\mathbf{M}_{\mathbf{4}}$ & $\mathbf{M S}_{\mathbf{4}}$ & $\mathbf{K}_{\mathbf{2}}$ & $\mathbf{P}_{\mathbf{1}}$ \\
$\mathbf{g}^{\circ}$ & 0 & 7 & 4 & 6 & 6 & 3 & 0 & 0 & 1 & 2 \\
& & -94 & 54 & 345 & 238 & 405 & 127 & 346 & 54 & 238 \\
\hline
\end{tabular}

Berdasarkan pengolahan data pasang surut (Tabel 1) di Perairan Gampong Lhok, Kecamatan Kuala Pesisir, Aceh dengan menggunakan metode admiralty, didapatkan hasil beberapa konstanta harmonik. Dari konstanta tersebut dapat diketahui nilai bilangan formzahl untuk menentukan tipe passang surut suatu wilayah. Didapatkan hasil nilai bilangan formzahl sebesar 0,841 yang termasuk ke dalam range $(0,25<\mathrm{F}<1,50)$, sehingga dapat disimpulkan bahwa tipe pasang surut di perairan Gampong Lhok yaitu campuran condong ganda dan tinggi muka air laut rata - rata / MSL (Mean Sea Level) dengan nilai sebesar $363 \mathrm{~cm}$.

Pasang surut merupakan salah satu faktor yang dapat mempengaruhi perubahan garis pantai. Untuk nilai elevasi penting lainnya yaitu HHWL (Highest High Water Level) 20 $\mathrm{cm}$, HWL (High Water Level) $470 \mathrm{~cm}$, LWL (Low Water Level) $243 \mathrm{~cm}$, dan LLWL (Lowest Low Water Level) sebesar $-20 \mathrm{~cm}$. Pasang surut merupakan suatu fenomena pergerakan naik turun permukaan air laut secara berkala yang diakibatkan oleh kombinasi gaya gravitasi dan gaya tarik - menarik benda - benda langit, terutama matahari, bumi, dan bulan. Pengaruh benda - benda angkasa lain dapat diabaikan karena jaraknya sangat jauh atau ukurannya lebih kecil. Faktor lain yang merupakan faktor non astronomi yang mempengaruhi pasang surut perairan semitertutup seperti teluk adalah bentuk garis pantai, topografi dasar perairan, tekanan atmosfer, angin, densitas air laut, arus laut, penguapan, dan curah hujan. Sifat pasang surut perambatan gelombang pasang surut menuju perairan dangkal yang berbentuk semitertutup dapat berubah, mengalami amplifikasi atau peredaman, tergantung mekanisme resonansi daerah tersebut [5]

\section{KESIMPULAN}

Dari hasil dan pembahasan yang dilakukan dalam penelitian ini, maka dapat diambil kesimpulan yaitu, pada tahun 2016 2020 kawasan pesisir Pantai Gampong Lhok mengalami akresi maksimum sebesar 30,16 $\mathrm{m} /$ tahun yaitu pada segmen 286 , sedangkan abrasi maksimum terjadi sebesar $-34,49$ $\mathrm{m} /$ tahun terjadi pada segmen 1259 .

Selain itu, Angin merupakan faktor utama dalam pembangkitan gelombang, sehingga arah dan kecepatan angin erat kaitannya dengan arah dan tinggi gelombang. Semakin tinggi kecepatan angin berhembus, semakin besar gelombang yang dihasilkan. Semakin besar gelombang, semakin besar energi yang dibawa, sehingga dampaknya terhadap 
peristiwa abrasi semakin besar. Gelombang yang merambat menuju daratan dengan sudut datang tertentu, dapat menimbulkan arus sejajar pantai akibat gelombang pecah yang berperan besar terhadap persebaran sedimen yang menjadi faktor perubahan garis pantai. Tingkat akurasi proses deliniasi darat dan laut sangat dipengaruhi kondisi pasang surut saat dilakukan akuisisi data citra satelit, sehingga dibutuhkan data citra satelit yang memiliki kondisi pasang surut yang sama dengan perbedaan tinggi muka air laut yang tidak terlalu besar.

\section{UCAPAN TERIMA KASIH}

Ucapan terima kasih penulis sampaikan kepada para dosen FPIK UB serta mahasiswa - mahasiswa yang telah membantu dalam penelitian ini.

\section{DAFTAR PUSTAKA}

[1] Aniendra, A.A., B. Sasmito, A. Sukmono. "Analisis Perubahan Garis Pantai dan Hubungannya dengan Land Subsidence Menggunakan Aplikasi Digital Shoreline Analysis System (DSAS) (Studi Kasus : Wilayah Pesisir Kota Semarang)" Jurnal Geodesi Undip, 9(1), 12 - 19. 2337 - 845X, 2020.

[2] Azizi, M. I., Hariyadi, Warsito A. "Pengaruh gelombang terhadap Sebaran Sedimen Dasar di Perairan Tanjung Kalian Kabupaten Bangka Barat." Jurnal Oseanografi, 6(1), 165 - 175, 2017.

[3] Fadilah, Suripin, dan D.P. Sasongko. "Menentukan Tipe Pasang Surut dan Muka Air Rencana Perairan Laut Kabupaten Bengkulu Tengah Menggunakan Metode Admiralty." Maspari Journal, 6(1), 1 - 12, 2087 0558,2014.

[4] Istiyono, A., Mauliddin, A. Iskandar. " Analisis Tinggi Gelombang Laut di
Perairan Sulawesi Tenggara dan Laut Banda ditinjau dari Perspektif Dinamika Meteorologi." Jurnal Geografi Aplikasi Dan Teknologi, 1(2), 59-68,25499181,2017.

[5] Kusmanto, E., M. Hasanudin, dan W. B. Setyawan. "Aplifikasi Pasang Surut dan Dampaknya terhadap Perairan pesisir Probolinggo." Osanologi dan Limnologi di Indonesia.1(3):69-80,2016.

[6] Gumilang, M. P. M."Analisis Hasil Koreksi Geometri Orthoektifikasi Citra Satelit Resolusi Tinggi dengan Menggunakan DEM SRTM, DEM ALOS-PALSAR, dan DEM NASIONAL (Studi Kasus Kecamatan Wonosari, Kabupaten Malang)" Institut Teknologi Nasional Malang.2020.

[7] Lubis, Darwin P., Mbina P., dan M. Ali N. Simanjuntak. "Analisis Perubahan Garis Pantai dengan Menggunakan Citra Penginderaan Jauh (Studi Kasus di Kecamatan Talawi Kabupaten Batubara)"Jurnal Geografi.9(1):2231,2017.

[8] Munanda dan I. Kusumawati. "Studi Analisis Faktor Penyebab dan Penanganan Abrasi Pantai di Wilayah Pesisir Aceh Barat." Jurnal Perikanan Tropis.4(1),47-56,2355-5564,2017.

[9] Suharyo, O.S., dan Zainul H. "Pemanfaatan Citra Satelit Resolusi Tinggi Untuk Identifikasi Perubahan Garis Pantai Pesisir Utara Surabaya." Jurnal Kelautan.12(1):89-96,2019.

[10] Wakkary, A. C. "Studi Karakteristik Gelombang pada Daerah Pantai Desa Kalinaung Kab. Minahasa Utara."Jurnal Sipil Statistik,5(3),167-174,23376732,2017. 